\title{
Plasma LH and testosterone responses to synthetic gonadotrophin-releasing hormone (GnRH) or dexamethasone-GnRH combined treatment and their relationship to semen output in bulls
}

\author{
G. Abdel Malak and M. Thibier* \\ Laboratoire d'Hormonologie, UNCEIA, BP 65, 94703 Maisons-Alfort, and \\ *Institut National Agronomique Paris-Grignon, 78850 Thiverval-Grignon, France
}

\begin{abstract}
Summary. The sperm output of each of 54 dairy bulls of the Montbeliarde breed was carefully investigated from 15 weekly semen collections at 51-65 weeks of age. Assessment of classical characteristics of semen output led to classification of bulls as good, medium and poor semen producers.

At 12 and 13 months of age, bulls were injected i.m. with $0.25 \mathrm{mg} \mathrm{GnRH}(\mathrm{N}=$ $25)$ or with $20 \mathrm{mg}$ dexamethasone $+0.25 \mathrm{mg} \mathrm{GnRH}(\mathrm{N}=29)$. Peripheral plasma $\mathrm{LH}$ and testosterone responses to these injections were evaluated from frequent sampling. In the two groups, the mean areas under the curve of $\mathrm{LH}(\mu \mathrm{g} / \mathrm{ml} \times 150$ min) were significantly different between bulls $(P<0.05)$. Intra-class correlation was 0.35 after the single GnRH administration $(P<0.05)$ and 0.57 after dexamethasone-GnRH $(P<0.05)$. This latter value indicates a predominant individual influence over the $\mathrm{LH}$ response to such a combined treatment. No significant individual differences were seen from the testosterone responses to either of these challenges. Correlations between individual LH responses and any of the semen output criteria were not significant $(P>0.05)$ and there were no significant differences in terms of mean LH responses between bulls in the 3 categories of semen production.
\end{abstract}

\section{Introduction}

The individual evaluation of the sexual function of a male involves many components. In bulls which are to be used for artificial insemination, semen output and endocrine secretions can not only be evaluated, but may also be critical for selection of sires (Thibier \& Colchen-Bourlaud, 1972b; Thibier, 1977a). Routine ejaculation (once weekly) can be used to discriminate individuals if collections are continued for 15 weeks (Thibier \& Colchen-Bourlaud, 1972b).

There have been many studies on the relationship of pituitary-testicular endocrine function and spermatogenesis in ruminants (see Courot, 1967; Courot et al., 1979), but as far as we know there has been no investigation, on a quantitative basis, of a relationship between concentrations of $\mathrm{LH}$ or testosterone and testicular exocrine function. This could give further insight on the hormonal control of spermatogenesis and on its practical use as an indicator of the sperm output ability, or even of fertility, as suggested by Bindon \& Turner (1974), Bindon, Chang \& Evans (1974), Thibier (1977a) and Land (1978). Because hormone concentrations fluctuate randomly during the day (Thibier, 1975a, 1976a), the magnitude of the LH and testosterone responses in each individual to a uniform challenge was used for assessment (Thibier, 1977a). 
Individual bulls respond to a single $\mathrm{GnRH}$ challenge in a repeatable manner when compared to their contemporaries after puberty (Thibier, 1976b, 1977a) or even before and after the onset of puberty (Chantaraprateep \& Thibier, 1979a). Similar data have been reported by D. B. Galloway \& T. Stelmasiak (unpublished observations) but Tyrrell, Starr, Restall \& Donnelty (1980) did not find such a significant repeatability in ram lambs because of the seasonal influences in this species.

The aim of the present study was to investigate for a large number of young bulls (1) the individual characteristics and repeatability of the $\mathrm{LH}$ and testosterone responses to a single GnRH challenge or a dexamethasone-GnRH treatment, and (2) the relationship of these responses to sperm output.

\section{Materials and Methods}

\section{Experimental animals and semen analysis}

This study involved 54 Montbéliarde bulls. They were introduced and kept under similar conditions (feeding and management) at the performance test station (U.MO.TEST, 01250 Ceyzériat) from the age of 15 days. At 43-50 weeks of age, the bulls were trained to go to the mounting room and to ejaculate into an artificial vagina. Semen was then collected (1st and 2 nd ejaculates) from each individual once weekly between 09:00 and 12:00 h. Before the first ejaculation, they were restrained for $10 \mathrm{~min}$ and allowed one false mount. There was a 5 -min interval between 1 st and 2 nd ejaculates. This routine semen collection was carried out for 15 consecutive weeks, i.e. 51-65 weeks of age.

Immediately after semen collection, ejaculates were evaluated by classical criteria (volume, sperm concentration, percentage of motility) as previously described (Thibier \& ColchenBourlaud, 1972a). The total number of spermatozoa was computed by multiplying volume by concentration of spermatozoa. Semen smears were made and stained with nigrosin-eosin to determine the percentage of spermatozoa with abnormal morphology (total, of head, tail, mid-piece, decapitated spermatozoa) and this was performed only on the 2nd ejaculates every other week because of its high repeatability (Colchen-Bourlaud \& Thibier, 1973). All this evaluation was estimated by the same person throughout the course of this study.

These data on semen characteristics were used to classify bulls into so-called good, medium and poor semen producers (see Thibier \& Colchen-Bourlaud, 1972b; Colchen-Bourlaud \& Thibier, 1973).

In the present study, calculations were made from individual means for the 15 weeks of experimental semen collection (elementary data).

\section{Hormonal challenges and blood sampling}

The first 25 bulls were given a single i.m. injection of $0.25 \mathrm{mg} \mathrm{GnRH}$ (Intervet, 49005 Angers, France) on two occasions 1 month appart (at 12 and 13 months of age). On each occasion the GnRH was given immediately after the first blood collection (at 08:00 h), and bled every $15 \mathrm{~min}$ for the first $150 \mathrm{~min}$, and thereafter every $60 \mathrm{~min}$ during the subsequent $4 \mathrm{~h} \mathrm{(15}$ samples in all). Of these 25 bulls 9 were classified according to semen quality as good, 9 as medium and 7 as poor.

The other 29 bulls were treated i.m. with $20 \mathrm{mg}$ dexamethasone (Intervet) at $08: 00 \mathrm{~h}$ and $5 \mathrm{~h}$ later, $0.25 \mathrm{mg} \mathrm{GnRH}$ was administered (i.m.). This combined treatment was given at 12 and 13 months of age. Blood samples were collected at 1-h intervals for $5 \mathrm{~h}$ starting just before the dexamethasone injection. After GnRH injection, blood was sampled as in the first experiment. Twelve of these 29 bulls were classified as good, 10 as medium and 7 as poor semen producers.

Peripheral blood samples were collected by jugular venepuncture into heparinized evacuated 
tubes. They were centrifuged at $3000 \mathrm{~g}$ for $10 \mathrm{~min}$ and plasma was separated and stored at $-20^{\circ} \mathrm{C}$ until required for assay.

\section{Hormonal assays}

LH and testosterone concentrations were measured by radioimmunoassay as previously described (Thibier, 1975a, 1976b).

A double-antibody method was used for the LH assay, with highly purified ovine LH (LER-1056-C C $_{2}$ ) iodinated with ${ }^{125}$ I (C.E.A., 91400 Saclay, France) as the labelled antigen. The average of duplicate determinations $(200 \mu \mathrm{l})$ of each sample was expressed in terms of the bovine reference standard B-LH-DSII (biological potency, $1.05 \mathrm{NIH-LH-S} \mathrm{units/mg).} \mathrm{Inter-} \mathrm{and}$ intra-assay coefficients of variation were 18 and $7.4 \%$ respectively and the detection limit was $0.25 \mathrm{ng} / \mathrm{ml}$.

Concentrations of testosterone were determined in duplicate. The antiserum was used at a dilution of $1 / 15000$. It cross-reacted only with $5 \alpha$-dihydrotestosterone $(50 \%)$. Negligible amounts of $5 \alpha$-dihydrotestosterone occur in the peripheral plasma of bulls (Thibier, 1977a). Inter- and intra-assay coefficients of variations were 11.6 and $10.2 \%$ respectively and the limit of sensitivity was $0.03 \mathrm{ng} / \mathrm{ml}$.

For an estimate of the amount of $\mathrm{LH}$ or testosterone released after $\mathrm{GnRH}$ or dexamethasone-GnRH treatment, a so-called total response has been used (Thibier, 1976b) and calculated from the area under the curve during $150 \mathrm{~min}$. This response is expressed as $\mu \mathrm{g} / \mathrm{ml} \times$ $150 \mathrm{~min}$.

The results are given in terms of mean \pm s.d. and comparisons were statistically evaluated by Student's $t$ test. The repeatability was estimated by calculation of the intra-class coefficient of correlation according to Snedecor \& Cochran (1956).

\section{Results}

\section{$L H$ and testosterone responses after GnRH treatment}

The administration of a single injection of $\mathrm{GnRH}$ led to a pronounced release of $\mathrm{LH}$ and testosterone (Text-fig. 1). As early as $15 \mathrm{~min}$ after treatment, $\mathrm{LH}$ concentrations were markedly elevated. The mean maximum levels $(69.3 \pm 31.1$ and $78.0 \pm 30.3 \mathrm{ng} / \mathrm{ml}$ at 12 and 13 months of age, respectively) occurred at $105 \mathrm{~min}$. Thereafter, the LH levels decreased continuously and pretreatment base-line levels were reached at about $6.5 \mathrm{~h}$ after $\mathrm{GnRH}$ treatment.

Mean plasma levels of testosterone after GnRH stimulation increased more slowly than those of $\mathrm{LH}$ and maximum values were maintained between 60 and $210 \mathrm{~min}$ after $\mathrm{GnRH}$ injections.

The mean areas under the $\mathrm{LH}$ curves were $8.4 \pm 2.9$ and $9.6 \pm 2.9 \mu \mathrm{g} / \mathrm{ml} \times 150 \mathrm{~min}$ at 12 and 13 months respectively $(P>0.05)$. Those of testosterone were $1.16 \pm 0.25$ and $1.05 \pm$ $0.29 \mu \mathrm{g} / \mathrm{ml} \times 150 \mathrm{~min}(P>0.05)$. No significant correlations were found between the mean individual total response of $\mathrm{LH}$ and testosterone after $\mathrm{GnRH}$ injection.

The analysis of variance of the total response of $\mathrm{LH}$ revealed significant individual effects $(P<0.05)$ and the intra-class correlation was 0.35 . By contrast the mean total response of testosterone was not significantly different between individuals $(P>0.05)$.

\section{$L H$ and testosterone responses to dexamethasone-GnRH combined treatment}

After dexamethasone treatment, mean concentrations of $\mathrm{LH}$ were significantly decreased to mean levels of about $0.5 \mathrm{ng} / \mathrm{ml}$ both at 12 and 13 months of age and very low variations were then seen between or within bulls, as shown by the low magnitude of the standard deviation (Text-fig. 2). 


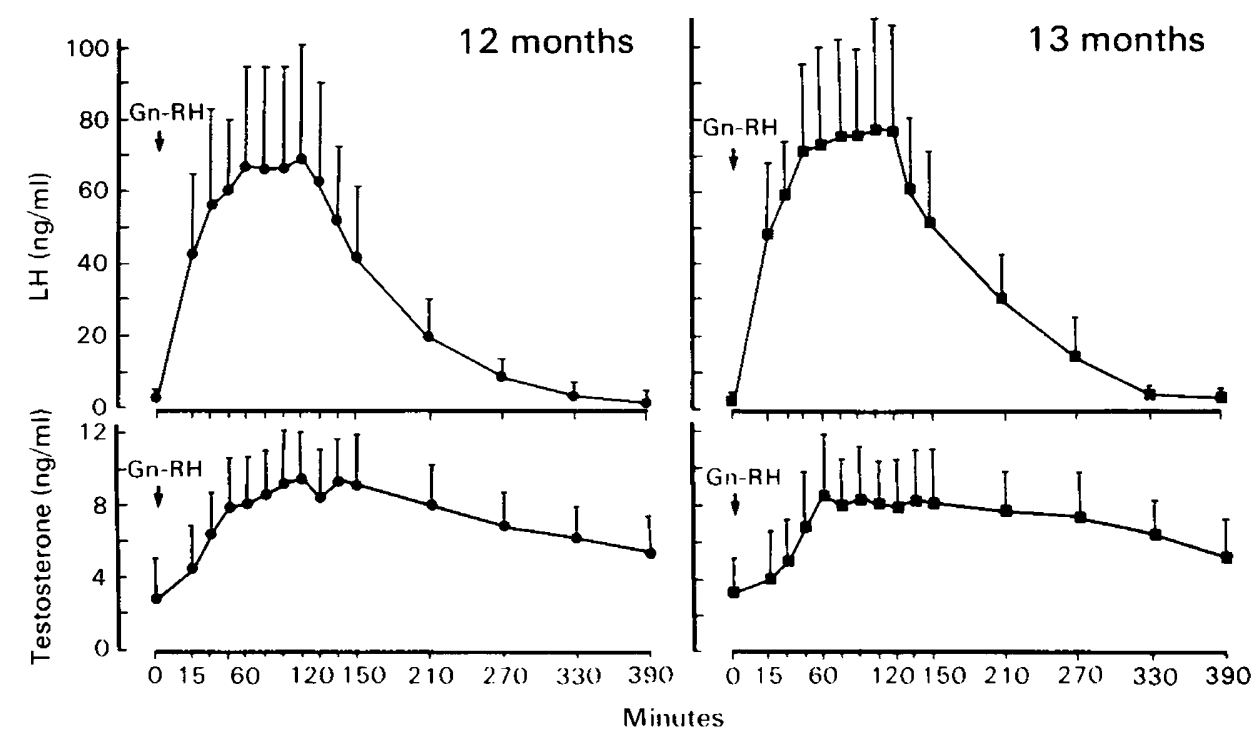

Text-fig. 1. Mean \pm s.d. plasma $\mathrm{LH}$ and testosterone concentrations in bulls $(\mathrm{N}=25)$ after treatment with $0.25 \mathrm{mg} \mathrm{GnRH}$ at 12 and 13 months of age.
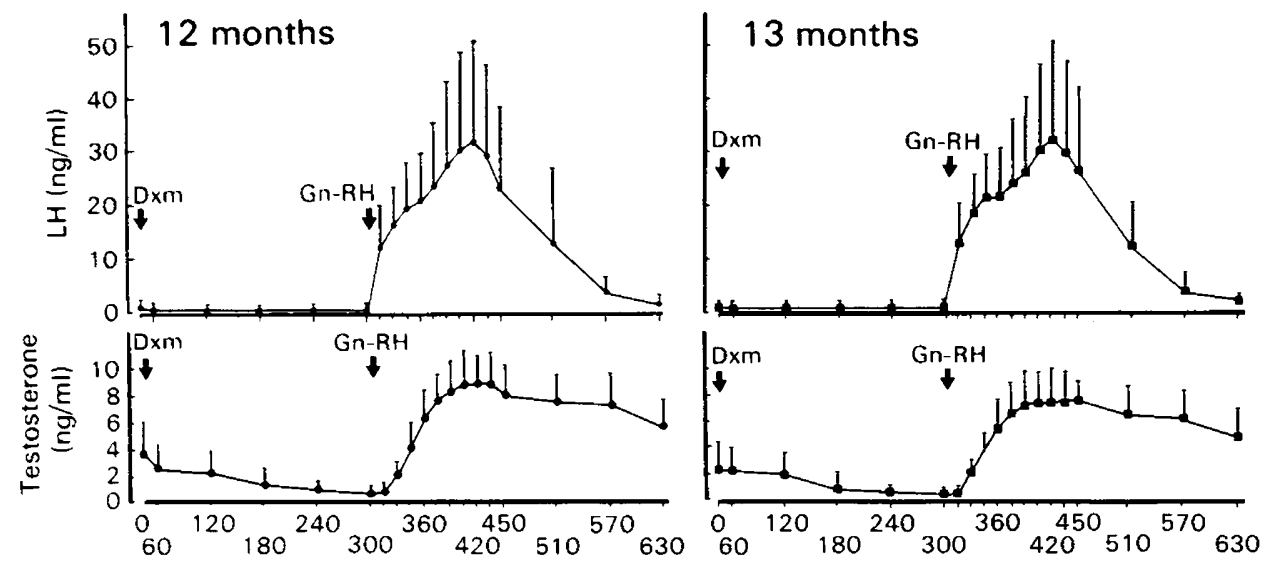

Minutes

Text-fig. 2. Mean \pm s.d. plasma $\mathrm{LH}$ and testosterone concentrations in 29 bulls after treatment with $20 \mathrm{mg}$ dexamethasone (Dxm) and $0.25 \mathrm{mg} \mathrm{GnRH}$ at 12 and 13 months of age.

Mean concentrations of testosterone had fallen to levels of $<0.5 \mathrm{ng} / \mathrm{ml}$ by the time of $\mathrm{GnRH}$ injection $5 \mathrm{~h}$ later (Text-fig. 2) and there was little variation between or within bulls. The GnRH challenge was followed by a quick rise in the LH concentrations up to mean maximum levels of about $32 \mathrm{ng} / \mathrm{ml}, 2 \mathrm{~h}$ later. The mean areas under the curves at 12 and 13 months did not differ significantly $(P>0.05)$, being $3.38 \pm 1.45$ and $3.46 \pm 1.49 \mu \mathrm{g} / \mathrm{ml} \times 150 \mathrm{~min}$ respectively, and they were significantly less $(P<0.05)$ than those after a single GnRH treatment. Subsequently, the testosterone levels increased up to values of about $8 \mathrm{ng} / \mathrm{ml}$ at the two ages. The mean areas under the curve were $0.88 \pm 0.20$ and $0.76 \pm 0.20 \mu \mathrm{g} / \mathrm{ml} \times 150 \mathrm{~min}(P>0.05)$.

Analysis of variance of the total responses of LH to the GnRH challenge revealed a significant effect of individuals and the computed intra-class correlation was 0.57 . There was no significant variation between bulls for the response of the testosterone concentrations and therefore no significant repeatability of the testosterone pattern. 


\section{Semen output characteristics}

Means of the main criteria for semen output evaluation are reported in Table 1. Volume of semen did not differ significantly between categories (data not shown). For all other parameters, the means between categories were significantly different $(P<0.05)$. For total sperm abnormalities, the variance of the 'poor' category was higher than and significantly different from those of the two other categories $(P<0.05)$.

Table 1. Mean characteristics per ejaculate of semen output (weekly collections from 51-65 weeks of age) of the 54 bulls according to classification categories

\begin{tabular}{llll}
\hline & Good semen & Medium semen & Poor semen \\
\hline No. of bulls & 21 & 19 & 14 \\
Total no. of spermatozoa $\left(\times 10^{9}\right)$ & $3.52 \pm 0.80$ & $2.18 \pm 0.55$ & $1.61 \pm 0.94$ \\
\% of motile spermatozoa & $67.3 \pm 3.8$ & $56.9 \pm 6.4$ & $44.0 \pm 15.4$ \\
\% total sperm abnormalities & $11.4 \pm 3.2$ & $14.9 \pm 6.1$ & $20.7 \pm 13.4$ \\
\hline
\end{tabular}

Values are mean \pm s.d.

Relationship between the total response of $L H$, testosterone after GnRH or dexamethasone$G n R H$ and the semen output characteristics

The results of the total responses are given in Table 2. Mean values for the bulls injected with GnRH alone were not statistically significantly different $(P>0.05)$.

The coefficient of correlation was calculated for each individual from the means of the sperm characteristics (1st and 2nd ejaculates) and the total responses of LH or testosterone concentrations after GnRH. There were no significant correlations $(P>0.05)$. Similarly, from the 29 bulls challenged with dexamethasone and $\mathrm{GnRH}$ the mean areas under the $\mathrm{LH}$ or testosterone curves (Table 2) did not vary significantly according to categories at either age. No linear correlations between LH or testosterone responses and semen output criteria of individuals were significant.

Table 2. Mean ( \pm s.d.) areas under the $\mathrm{LH}$ and testosterone curves in response to a single GnRH challenge or a combined dexamethasone $+\mathrm{GnRH}$ treatment according to semen output classification

\begin{tabular}{|c|c|c|c|c|c|c|c|}
\hline \multirow[b]{2}{*}{$\begin{array}{c}\text { Age } \\
\text { (months) }\end{array}$} & \multirow[b]{2}{*}{$\begin{array}{l}\text { Semen } \\
\text { category }\end{array}$} & \multicolumn{3}{|c|}{$\operatorname{Gn} \bar{R} \mathbf{H}$} & \multicolumn{3}{|c|}{ Dexamethasone + GnRH } \\
\hline & & $\begin{array}{c}\text { No. } \\
\text { of } \\
\text { bulls }\end{array}$ & $\begin{array}{c}\mathrm{LH} \\
(\mu \mathrm{g} / \mathrm{ml} \times 150 \mathrm{~min})\end{array}$ & $\begin{array}{c}\text { Testosterone } \\
(\mu \mathrm{g} / \mathrm{ml} \times 150 \mathrm{~min})\end{array}$ & $\begin{array}{c}\text { No. } \\
\text { of } \\
\text { bulls }\end{array}$ & $\begin{array}{c}\text { LH } \\
(\mu \mathrm{g} / \mathrm{ml} \times 150 \mathrm{~min})\end{array}$ & $\begin{array}{c}\text { Testosterone } \\
(\mu \mathrm{g} / \mathrm{ml} \times 150 \mathrm{~min})\end{array}$ \\
\hline 12 & $\begin{array}{l}\text { Good } \\
\text { Medium } \\
\text { Poor }\end{array}$ & $\begin{array}{l}9 \\
9 \\
7\end{array}$ & $\begin{array}{l}8.47 \pm 4.27 \\
9.31 \pm 2.75 \\
7.13 \pm 2.42\end{array}$ & $\begin{array}{l}1.10 \pm 0.34 \\
1.19 \pm 0.23 \\
1.34 \pm 0.24\end{array}$ & $\begin{array}{r}12 \\
10 \\
7\end{array}$ & $\begin{array}{l}3.25 \pm 0.75 \\
3.13 \pm 1.45 \\
3.65 \pm 2.30\end{array}$ & $\begin{array}{l}0.87 \pm 0.17 \\
0.90 \pm 0.20 \\
0.90 \pm 0.28\end{array}$ \\
\hline 13 & $\begin{array}{l}\text { Good } \\
\text { Medium } \\
\text { Poor }\end{array}$ & $\begin{array}{l}9 \\
9 \\
7\end{array}$ & $\begin{aligned} & 8.69 \pm 3.5 \\
& 10.35 \pm 2.07 \\
& 8.63 \pm 3.16\end{aligned}$ & $\begin{array}{l}1.07 \pm 0.4 \\
1.00 \pm 0.24 \\
1.09 \pm 0.29\end{array}$ & $\begin{array}{r}12 \\
10 \\
7\end{array}$ & $\begin{array}{l}3.47 \pm 1.51 \\
3.50 \pm 1.58 \\
3.39 \pm 1.53\end{array}$ & $\begin{array}{l}0.78 \pm 0.19 \\
0.70 \pm 0.20 \\
0.85 \pm 0.19\end{array}$ \\
\hline
\end{tabular}

\section{Discussion}

Mean patterns of $\mathrm{LH}$ and testosterone after GnRH challenge in the present study are in good agreement with previous reports for dairy bulls of the same age (Thibier, 1976b, 1977a; Chantaraprateep \& Thibier, 1979a). The mean total responses as estimated by the area under the curve do not vary significantly between the ages of 12 and 13 months in accordance with 
previous studies with fewer bulls (Thibier, 1976b; Chantaraprateep \& Thibier, 1979a). The LH release curves varied significantly according to individuals and the intra-class correlation was significant, thus indicating that the $\mathbf{L H}$ response depends upon each individual's phenotype. However, the intra-class correlation coefficient was not very high $(0.3)$, suggesting that this type of LH response also depends upon environmental factors, as reported previously for a small number of young bulls challenged before and after puberty (Chantaraprateep \& Thibier, 1979a). Oltner, Lundström \& Edqvist (1979) reported a coefficient of repeatability of 0.4 for the LH response to a $\mathrm{GnRH}$ challenge in three pairs of monozygous twin bulls aged 1.5 years.

The patterns of testosterone concentrations after the GnRH injections in this large number of bulls were also in full agreement with what has been previously reported on a smaller scale (Thibier, 1976a, 1977a; Chantaraprateep \& Thibier, 1979a). Again there was no significant variation according to age or to individuals and we conclude that, unlike $\mathrm{LH}$, the testosterone response to a GnRH challenge is mainly dependent upon external factors. This is also consistent with the absence of significant correlation between $\mathrm{LH}$ and testosterone areas under the curves.

The consequences of dexamethasone injections observed in the present study from 29 bulls entirely confirm previous observations by Thibier \& Rolland (1976) and Thibier (1977b), in that not only were the mean LH and testosterone levels lowered, but also the standard deviation was markedly reduced. Similarly, dexamethasone priming partly diminished the LH response to the GnRH challenge as demonstrated earlier (Thibier, 1977b; Chantaraprateep \& Thibier, 1979b). It was suggested by in-vivo data (Thibier, 1977b) that this effect was mediated by a partial inhibition of the GnRH to synthesize and release $\mathrm{LH}$ from the pituitary. Recent evidence in vitro from Li \& Wagner (1980) seems to reinforce this hypothesis. The present finding of an almost doubled intra-class correlation $(0.57)$ of the $\mathrm{LH}$ response to $\mathrm{GnRH}$ after dexamethasone priming as after a single GnRH challenge would suggest that use of this synthetic glucocorticoid would give a better revelation of the inherent potential of LH synthesis and release by any one individual.

The classification of bulls according to semen characteristics did lead to 3 distinct categories. For example, in the poor category, bulls had less than half of the sperm density, two-thirds of the sperm motility and almost twice as many sperm abnormalities than did bulls in the good category.

No correlation was found between the $\mathrm{LH}$ or testosterone responses to the treatments and any of the semen output characteristics. The $\mathrm{LH}$ responses to the dexamethasone-GnRH combined treatment, although highly repeatable, did not appear to be significantly correlated to the sperm output. Moreover, there was no significant variation in the mean areas under the curves between the bulls that were ranked in the good, medium or poor semen producing categories. Previous investigators have failed to show a significant relationship in bulls at this age between testosterone levels and semen output characteristics (Rawlings, Hafs \& Swanson, 1972; Thibier, 1975b; Sitarz, Erb, Martin \& Singleton, 1977) but the frequency of blood or semen sampling was too low to allow any definite conclusion. Some authors have reported that plasma LH concentrations in men with oligo- or azoospermia are more elevated than in other groups (Christiansen, 1975; Hopkinson, Mauss, Schenk, Fritze \& Hirschhäuser, 1977; Courtant \& Comhaire, 1978; Fossati, Asfour, Blacker, Bouteny \& Hermand, 1979), but in other studies there was no correlation between basal serum LH values and sperm count (Fossati et al., 1979).

Although the methodology of semen collection that we used was satisfactory to discriminate individuals on their semen output characteristics (Thibier \& Colchen-Bourlaud, 1972a), the latter were not closely related to the daily sperm production which requires determination by intensive semen collection (Thibier, 1977a). It cannot therefore be entirely excluded that there is no relationship between an individual bull's LH secretion characteristics and the exocrine function of the testis.

Further investigation is needed to determine whether hormonal criteria may be related to fertility or sperm production characteristics and hence be a clue for early selection purposes. 
We thank Dr Constantin (Intervet, 49005 Angers, France) for GnRH; Dr L. E. Reichert for the ovine LH preparation (LER $1056 \mathrm{C}_{2}$ ); Dr D. Schams for the LH Standard antiserum; M. Cornier, Director of the U.MO.TEST (01250 Ceyzeriat, France), and G. Derrier for their welcome at the test station; M. F. Mercier for technical assistance; Mrs N. Jeanguyot and Mrs Y. Abdel Malak for help.

\section{References}

Bindon, B.M. \& Turner, H.N. (1974) Plasma LH of the prepubertal lamb: a possible indicator of fecundity. $J$. Reprod. Fert. 39, 85-88.

Bindon, B.N., Chang, T.S. \& Evans, R. (1974) Genetic effects on $\mathrm{LH}$ release by oestradiol and gonadotrophin releasing hormone in prepubertal lambs. J. Reprod. Fert. 36, 477, Abstr.

Chantaraprateep, P. \& Thibier, M. (1979a) LH and testosterone responses to gonadoliberin (LRH) treatment in young bulls prior to and during puberty. Annls Biol. anim. Biochim. Biophys. 19, 637-646.

Chantaraprateep, P. \& Thibier, M. (1979b) Effects of dexamethasone and testosterone propionate on $\mathbf{L H}$ response to gonadoliberin (LRH) in young post pubertal bulls. Andrologia 11, 25-32.

Christiansen, P. (1975) Studies on the relationship between spermatogenesis and urinary levels of follicle stimulating hormone and luteinizing hormone in oligospermic man. Acta endocr., Copenh. 78, 192-208.

Colchen-Bourlaud, M.A. \& Thibier, M. (1973) Connaissance de la fonction sexuelle du jeune reproducteur. Elev. \& Insém. 136, 3-37.

Courot, M. (1967) Endocrine control of the supporting and germ cell of the impuberal testis. $J$. Reprod. Fert., Suppl. 2, 89-101.

Courot, M., Hochereau de Reviers, M.T., Monet-Kuntz, C., Locatelli, A., Pisselet, C., Blanc, M.R. \& Dacheux, Y.L. (1979) Endocrinology of spermatogenesis in the hypophysectomised ram. J. Reprod. Fert. 26, 165-173.

Courtant, G. \& Comhaire, M. (1978) Evaluation clinique, hormonale et spermiologique chez 25 cryptorchides. Annls Endocr. 39, 427-437.

Fossati, P., Asfour, M., Blacker, C., Bouteny, J.J. \& Hermand, E. (1979) Serum and seminal gonadotropins in normal and infertile men: correlations with sperm count, prolactinemia and seminal prolactin. Arch. Androl. 2, 247-252.

Hopkinson, C.R.N., Mauss, J., Schenk, B., Fritze, E. \& Hirschhäuser, G. (1977) Some interrelationship between plasma levels of LH, FSH, oestradiol-17 $\beta$, androgens and semen analysis data in male infertility patients. Andrologia 9, 216-239.

Land, R.B. (1978) Genetic improvements of mammalian fertility. A review of opportunities. Anim. Reprod. Sci. 1, 109-135.

Li, P.S. \& Wagner, W.C. (1980) Effect of hyperadrenal states on LH secretion in cattle. Proc. 9th Int. Congr. Anim. Reprod. \& AI., Madrid, Vol.3, p. 83, Abstr.

Oltner, R., Lundström, K. \& Edqvist, L.R. (1979) LH and testosterone in monozygous growing bulls (repeatability and variation with and without $\mathrm{GnRH}$ stimulation). Swedish J. Agric. Res. 9, 151-161.

Rawlings, N.C., Hafs, H.D. \& Swanson, L.V. (1972) Testicular and blood plasma androgens in Holstein bulls from birth through puberty. J. A nim. Sci. 34, 435-440.

Sitarz, N.E., Erb, R.E., Martin, T.G. \& Singleton, W.L (1977) Relationship between blood plasma testosterone, weaning treatment, daily gains and certain physical traits of young angus bulls. J. Anim. Sci. 45, 342-349.

Snedecor, G. W. \& Cochran, W.G. (1956) Statistical Methods, 5th edn. Iowa State University Press, Ames.

Thibier, M. (1975a) Variations circadiennes de la LH plasmatique chez le jeune taurillon. Annls Endocr. 36, 205-210.

Thibier, M. (1975b) Peripheral plasma testosterone concentrations in bulls around puberty. J. Reprod. Fert. 42, 567-569.

Thibier, M. (1976a) Diurnal testosterone and 17ahydroxyprogesterone in peripheral plasma of young post-pubertal bulls. Acta endocr., Copenh. 81, 623634.

Thibier, M. (1976b) Effect of synthetic gonadotropin releasing hormone $(\mathrm{Gn} / \mathrm{RH})$ on circulating luteinizing hormone (LH) and testosterone in young postpubertal bulls. Acta endocr., Copenh. 81, 635-643.

Thibier, M. (1977a) Contribution à l'étude de la fonction sexuells du jeune taurillon. Thése de Doctorat d'Etat ès Sciences, Université P. \& M. Curie (Paris VI).

Thibier, M. (1977b) Influence of dexamethasone (DXM) on $\mathrm{LH}$ and testosterone concentrations following gonadoliberin (LH-RH) treatment in young postpubertal bulls. In Recent Progress in Andrology, pp. 331-335. Eds A. Fabbrini \& E. Steinberger. Academic Press, London.

Thibier, M. \& Colchen-Bourlaud, M.A. (1972a) Le choix du jeune taurillon sur sa fonction sexuelle. Elev. \& Insém. 127, 3-43.

Thibier, M. \& Colchen-Bourlaud, M.A. (1972b) Le choix du jeune taurillon sur sa fonction sexuelle. Elev. \& Insém. 128, 3-23.

Thibier, M. \& Rolland, O. (1976) The effect of dexamethasone (DXM) on circulating testosterone (T) and luteinizing hormone (LH) in young postpubertal bulls. Theriogenology 5, 53-60.

Tyrrell, R.N., Starr, B.G., Restall, B.J. \& Donnelty, J.B. (1980) Repeatability of LH responses by lambs to monthly challenge with synthetic gonadotrophin releasing hormone (Gn/RH). Anim. Reprod. Sci. 3, 155-160. 